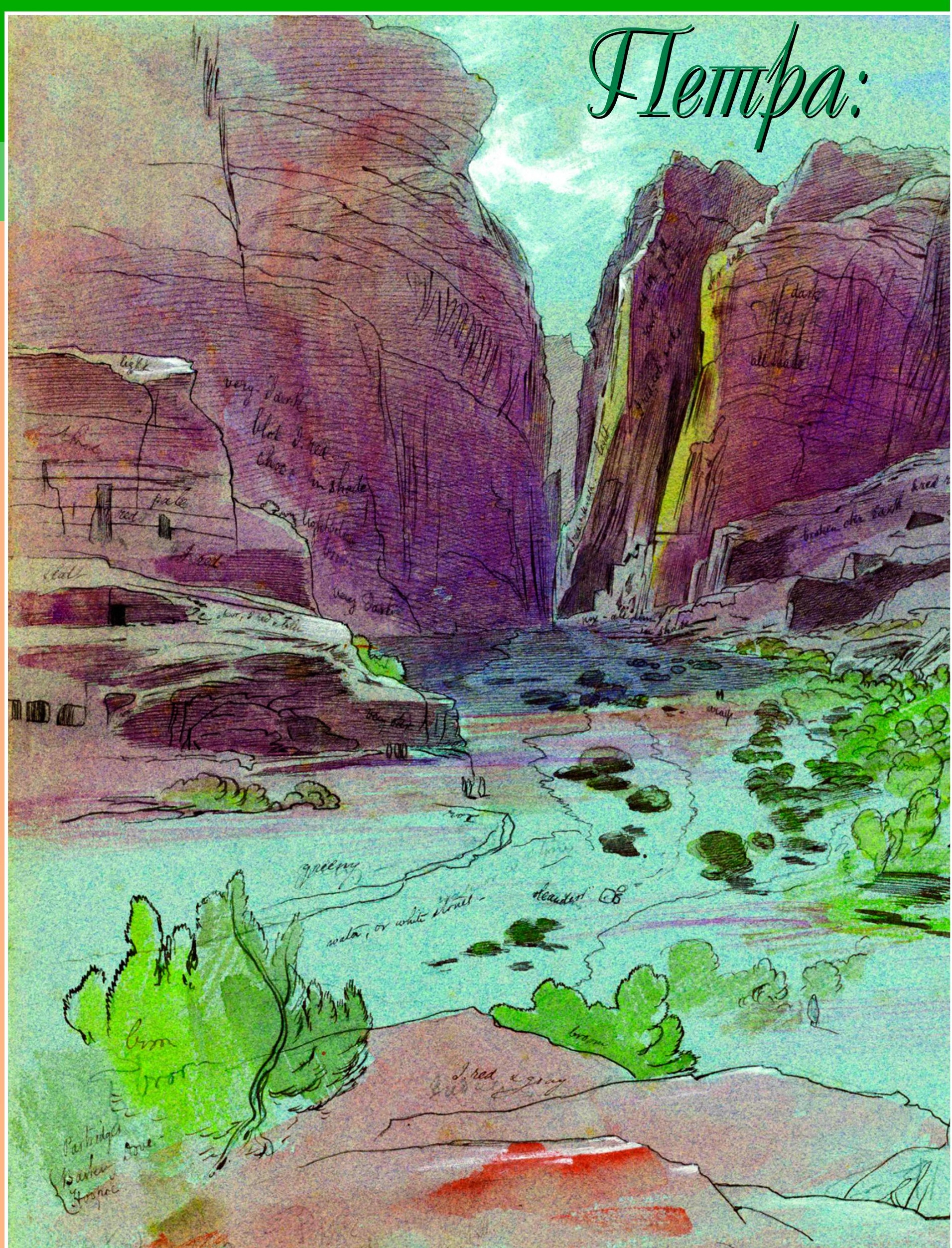




\section{В03В РОТИВШОЯСА}

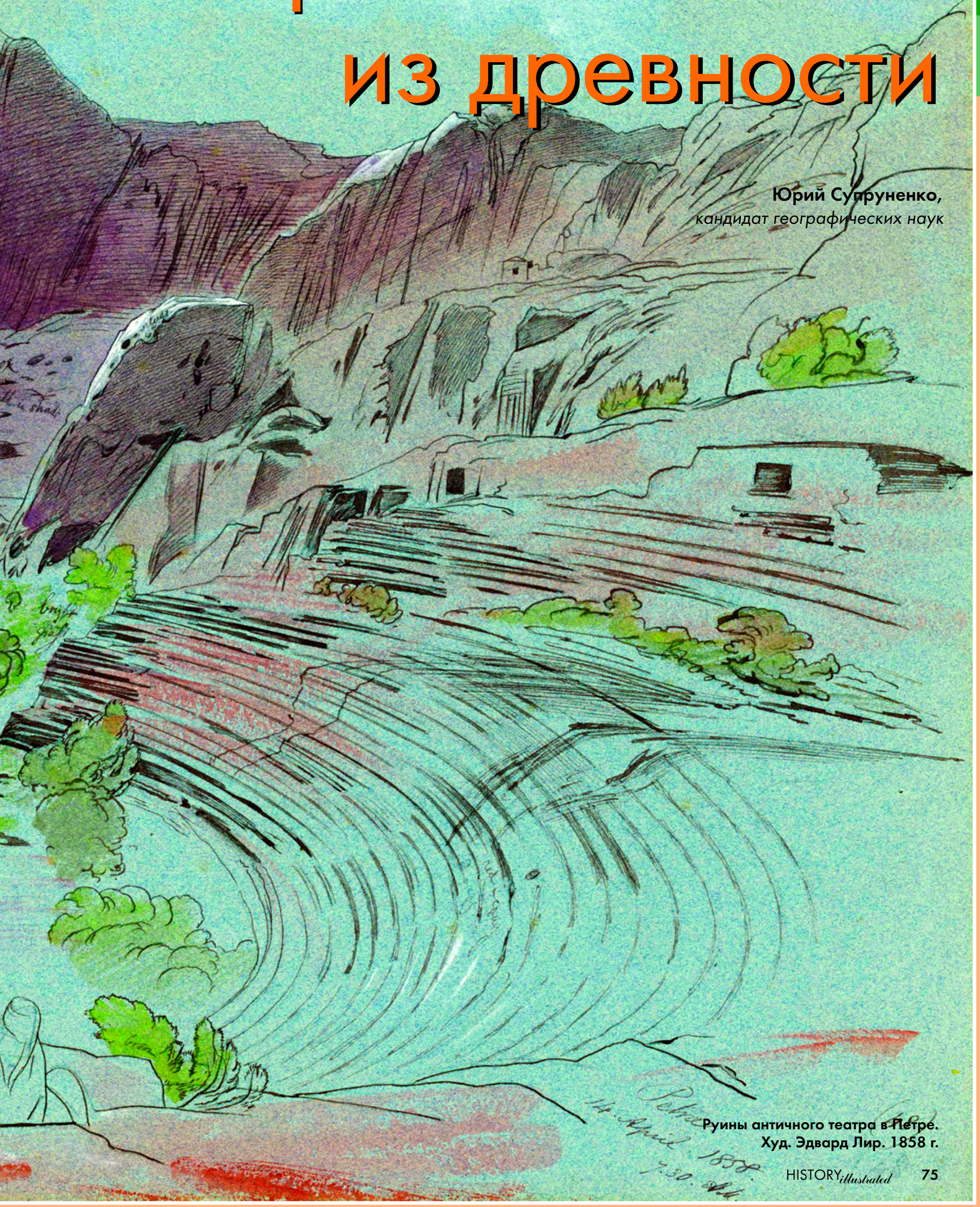




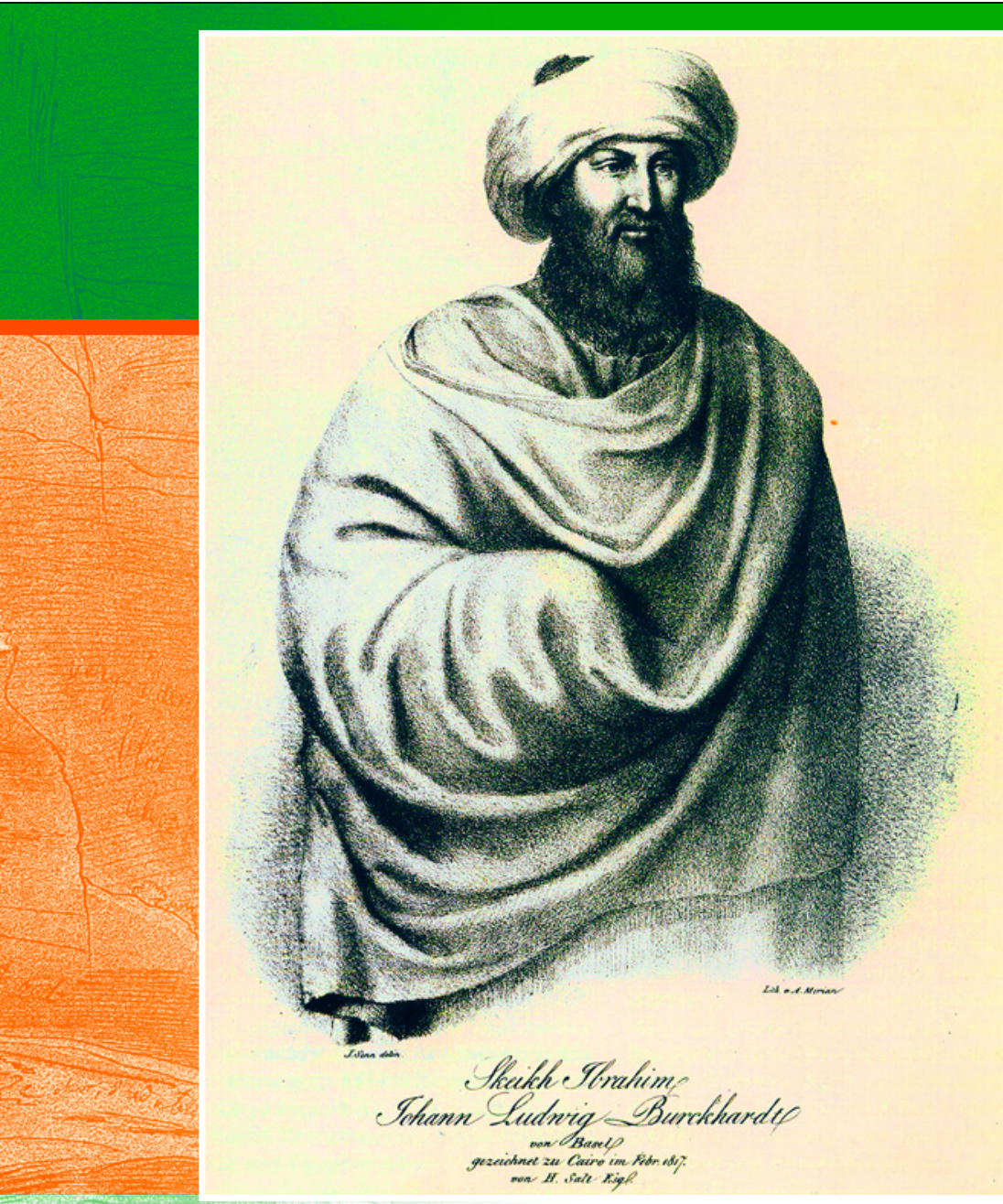

Иоганн Людвиг Буркхардт. Гравюра XIX в.

красный, то в пурпурный или оранжевый цвета. Постройки Петры, главным образом, являются наследством набатеев, отважных воинов и трудолюбивых каменотесов, которые обосновались на юге Иордании более двух тысяч лет назад. Строительство его продолжалось и при римлянах, византийцах, арабах. В XII веке Петрой владели крестоносцы. Но последующие века почти на тысячу лет изгладили саму память о существовании скального города, и заново он был открыт лишь в начале XIX столетия.

Существуют две различные версии обнаружения Петры, впрочем, солидарные в главном: это открытие принадлежит швейцарскому востоковеду Иоганну Людвигу Буркхардту, прославившемуся путешествиями по Ближнему и Среднему Востоку под именем Ибрагим ибн Абдалла. По одной, он, в поисках могилы пророка Аарона, оказался в древнем городе случайно. По другой версии, о существовании некоего таинственного города в скалах он слышал ранее и искал его специально. Зная, что местные жители прячут город от глаз чужеземцев, он даже вынужден был прибегнуть к мистификации. Добравшись в 1809 году до сирийского города Халеба, он выдал себя за «шейха», приехавшего изучать законы шариата. За три года в Сирии Буркхардт в совершенстве овладел арабским языком и настолько глубоко изучил Коран, что впоследствии даже смог написать к нему научный комментарий. Глубокое проникновение в исламскую культуру и помогло ему посещать развалины древних цивилизаций, неизвестные европейцам, которым по религиозным соображениям дорога туда была заказана.

Привал бедуинов в Петре.

Худ. Дэвид Робертс. 1829 г. 
Караван в пустыне. Шарль Теодор Фрер. 1850-е гг. Внизу: Петра. Худ. Дэвид Робертс. 1829 г.
Что же касается открытия набатейской столицы Петры, благодаря которому его имя навсегда осталось в истории, то в некотором смысле оно действительно было случайностью. Главной целью, которая привела Буркхардта на Восток, был переход через Сахару к истокам Нигера, для чего он под видом сирийского купца переедет в 1812 году в Каир, который до последнего дня его жизни, станет для него вторым домом.

Петру Буркхардт открыл в том же году, отправившись с караваном от

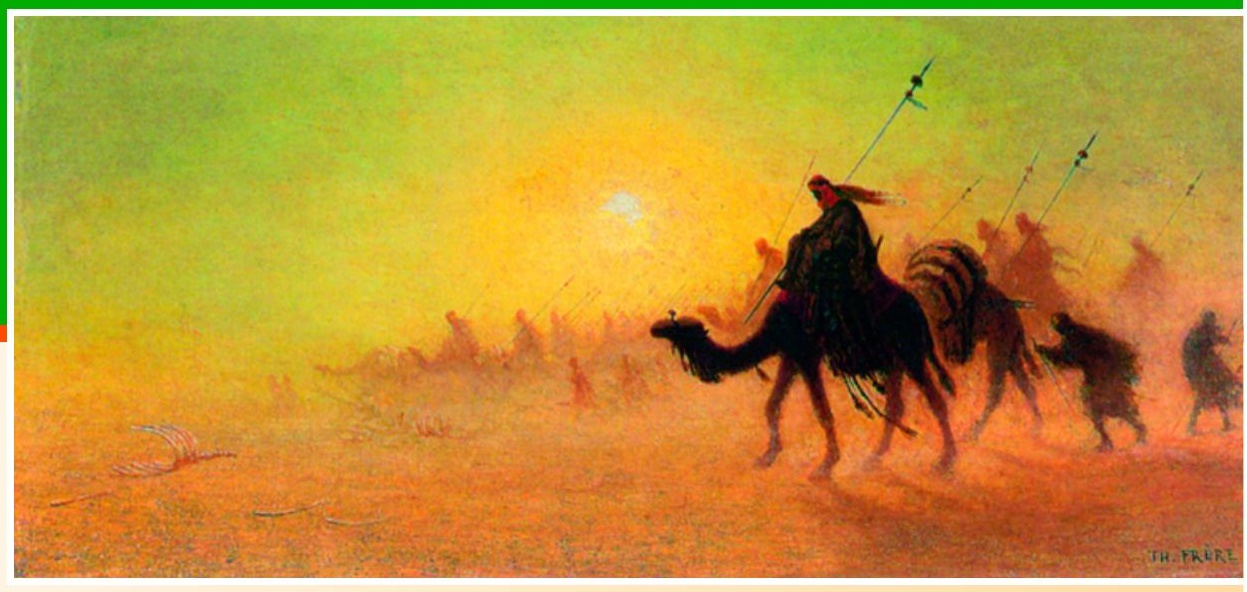

Главной целью, которая привела Буркхардта на Восток, был переход через Сахару к истокам Нигера, для чего он под видом сирийского купца переедет в 1812 г. в Каир, который станет для него вторым домом. Петру он открыл в том же году, отправившись с караваном от Дамаска до Каира.

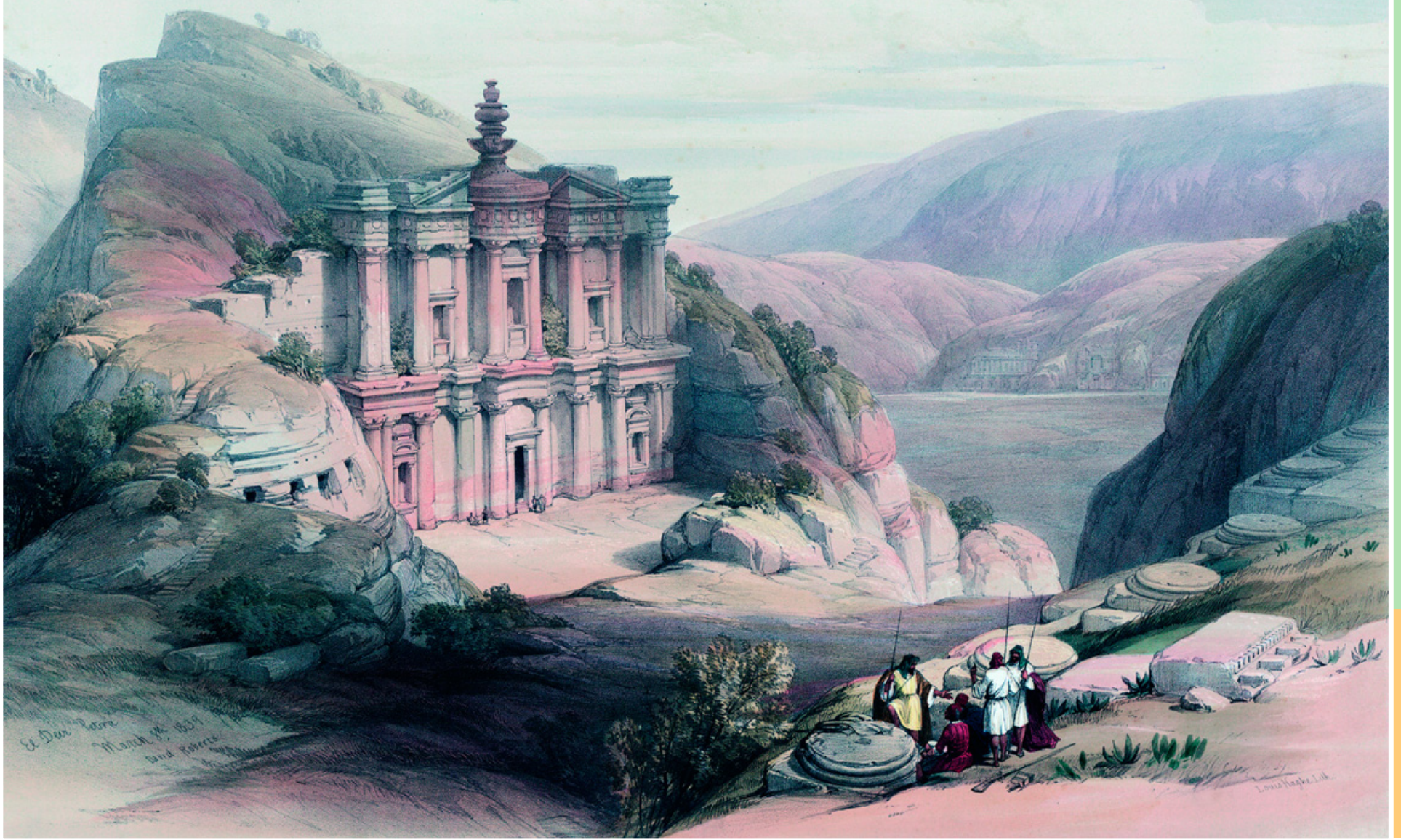




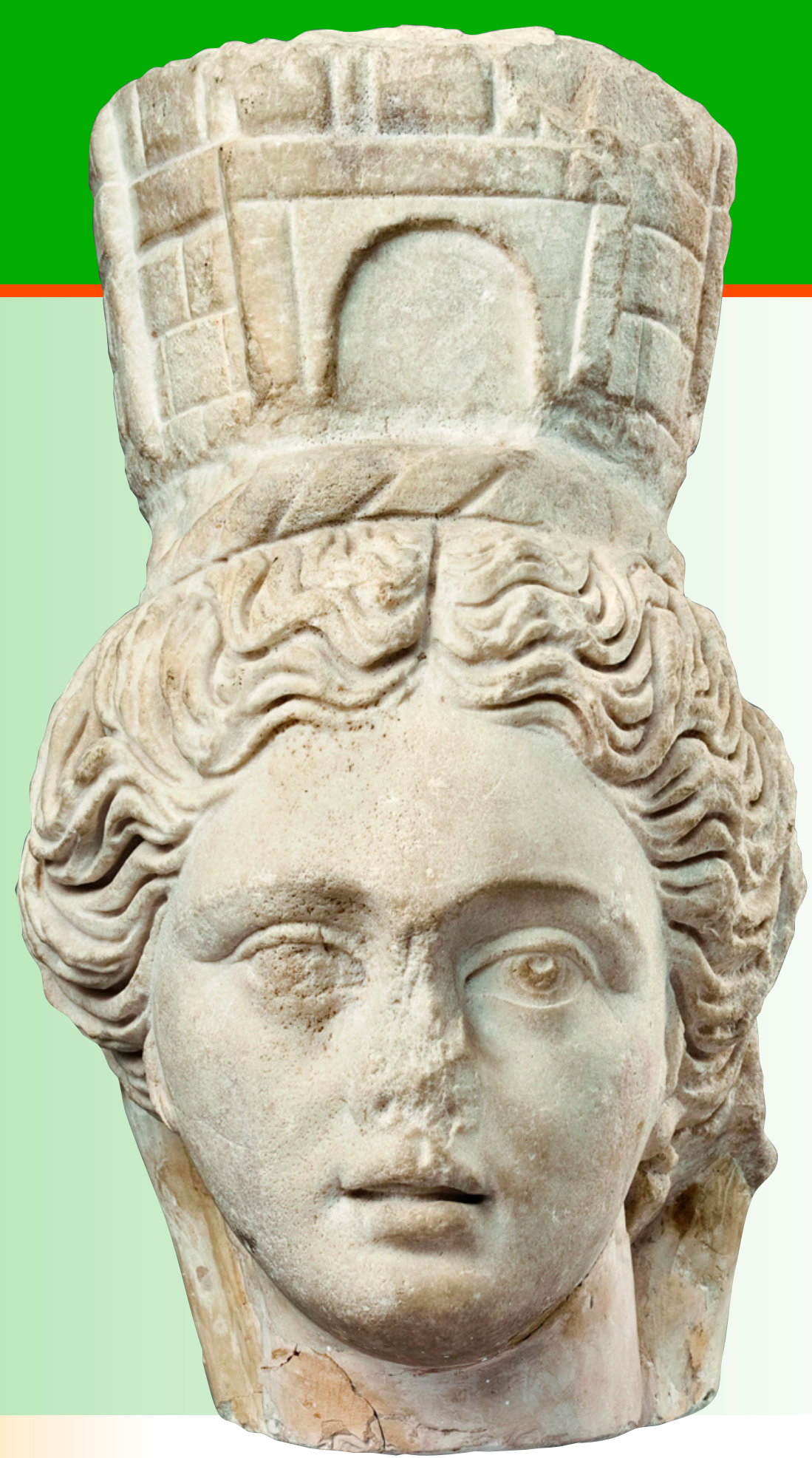

Дамаска до Каира. Иоганн был из тех любознательных европейцев, кто после экспедиции Наполеона в Египет, воспылал интересом к восточным странам. Миссионеры, пилигримы, иногда под видом мусульманских купцов и дервишей, старались пробраться с караванами к легендарным местам в пустыне, упомянутым в Библии. Города, которые никто не видел со времен падения Римской империи, будоражили
Набатейская богиня Манат - одна из трех самых почитаемых арабами доисламских богинь.

Считалась богиней судьбы, возмездия, царицей загробного мира

и хранительницей могильного покоя.

кого халифа Гарун ар-Рашида, героя сказок «Тысяча одна ночь», прославленного в песнях и преданиях. Эта гора считалась столь же священной для правоверных мусульман, как Хира около Мекки, и потому неверным было запрещено приближаться к ней под страхом смерти.

В ее окрестностях, по соображениям Буркхардта, и должна была находиться могила библейского пророка Аарона, которую он решил посетить, оторвавшись на какое-то время от каравана. Дорога, как он разузнал ранее, вела через расщелину Сик, образовавшуюся, по преданию, от удара посоха Моисея. Караванщики, случалось, проникали в нее, но ни о маршруте, ни тем более, о каких-то подробностях распространяться не хотели, и Буркхардт пустился в путь, что называется, на свой страх и риск.

Расщелина чернела пугающими тенями с двадцатиметровыми обрывами по сторонам. Тропа, виляющая по узкому дну, устланному обкатанными камнями - вероятно, путь здесь проложила когда-то вода, неожиданно вывела из ущелья к заброшенному древнему городу.

«В конце узкого и извилистого ущелья Эк-Сик, петляющего длиной в километр и спочти смыкаюоцимися на высоте более 90 скалами, писал позже путешественник, - неожиданно возникает легендарная столица набатейских племен, правивших южной Иорданией еще в VII веке до PX. Мой nуть пересекали скалистые формащии самых странных и причудливых форм, изумительные геологические пейзажи, богатые окраской, возникаюоцей при смешении различных минеральных составов окружаюших скал. Узкая горловина ущелья, прочерченная обрывами цвета розы, с измене- 


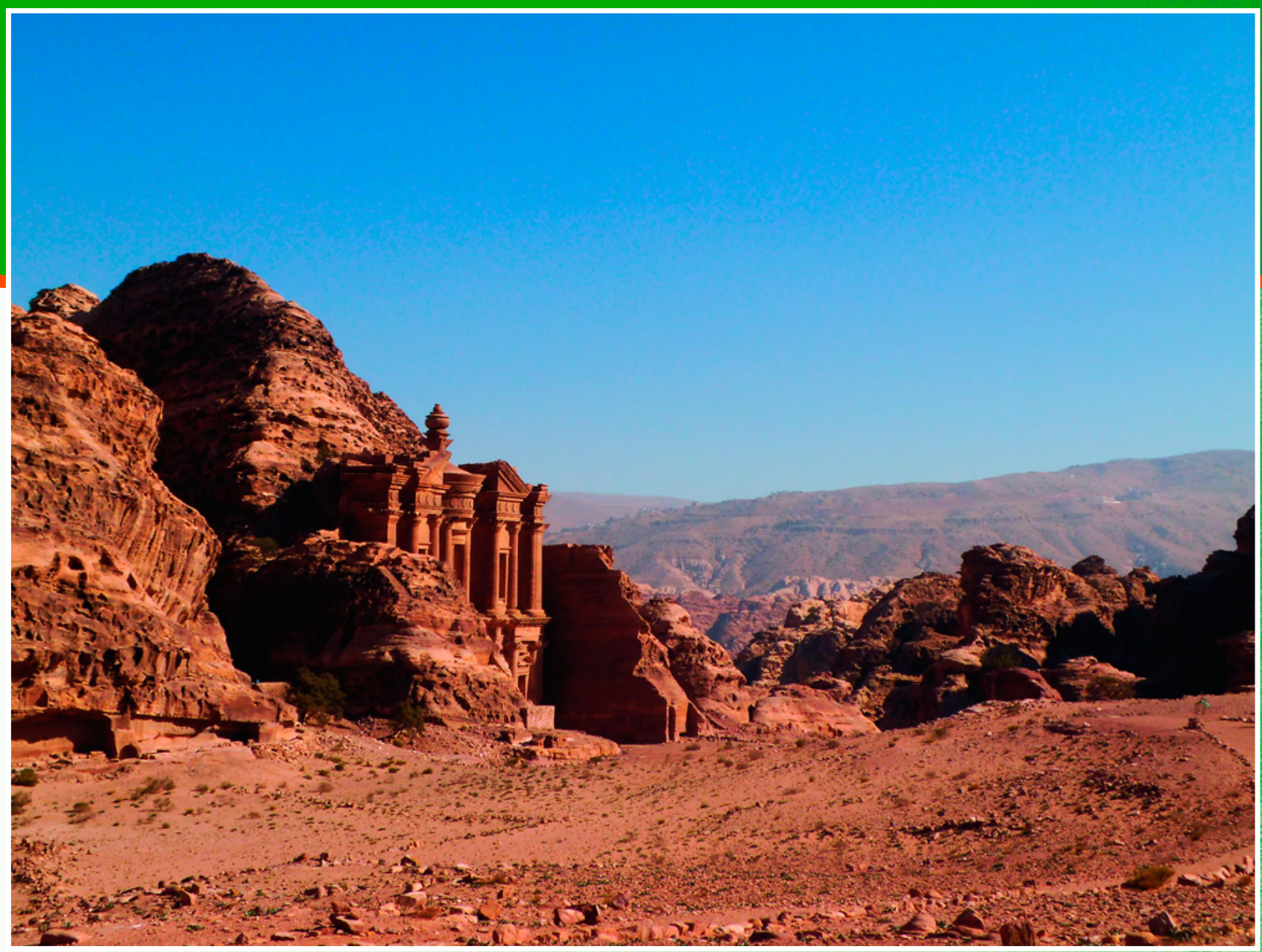

Набатейский храм-мавзолей Эль-Хазне в Петре.

Фасад монументального здания, целиком вырезанного из скалы в I веке, составляет 40 метров в высоту и 25 метров в иирину. Согласно одной из версий, храм выстроил набатейский иарь Арефа IV Филопатр в качестве собственной усыпальницы.

нием освещения приобретаетудивительные терракотовые оттенки, становящиеся еще более таинственными, благодаря при родным рисункам и разводам. Время от времени я бросал взгляд наверх, где вершины скал сужались надо мной, оставляя только щель, в которую с интересом заглядывала небесная синева.

Дорога вела через расщелину Сик. Караванщики, случалось, проникали в нее, но ни о маршруте, ни тем более, о каких-то подробностях распространяться не хотели, и Буркхардт пустился в путь, что называется, на свой страх и риск. Расщелина чернела пугающими тенями с двадцатиметровыми обрывами по сторонам. Тропа, виляющая по узкому дну, устланному обкатанными камнями - вероятно, путь здесь проложила когда-то вода, - неожиданно вывела из ущелья к заброшенному древнему городу. 

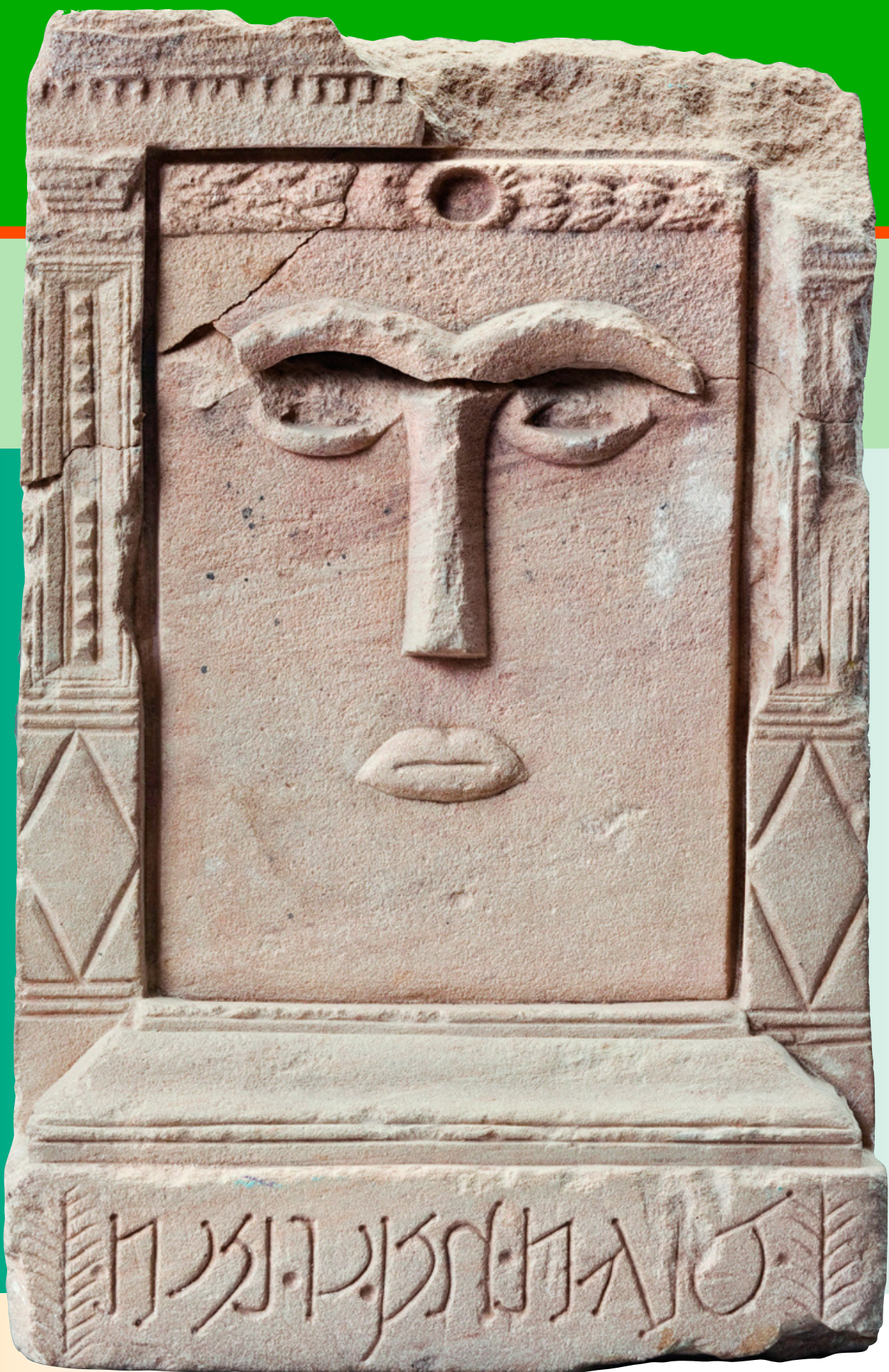

Высеченные в скалах дворцы, храмы, дома - желтые, голубые, пурпурные, белые, черные - напоминали чудесные восточные ковры. По мере вхождения в мир естественных красок Буркхардту стало видно, что все здания монолитные. Колонны, пышные портики, парадные входы были вырублены в скалах. Большинство фасадов оказались иллюзорными, неглубоко врезан-
Вотивный рельеф из Петры с надписью набатейским письмом:

«Богам от сына Найбата». І в. н.э.

Археологический музей Петры,

Иордания.

Орел. $\rightarrow$

Набатейское искусство. І в. н.э.

Археологический музей Петры,

Иордания.

Возвратившись к караванщикам, Буркхардт продолжил путь..

Отчет о чудесном городе у подножья горы Гаруна был опубликован только через десять лет после смерти автора. Книга «Путешествие по Сирии и Святой земле», вышедшая в свет в 1822 году, в которой был помещен и рассказ о Петре, тут же вызвала яростные споры о том, кто же построил удивительный город у священной горы. Поначалу библеисты горячо настаивали на том, что это тот самый Синай, упоминаемый в Библии, где останавливались евреи во время своего исхода, они и построили таинственное поселение. В подтверждение этой версии приводились и документы, в которых упоминалось свидетельство хрониста короля крестоносцев Болдуина I Фулчера, побывавшего в этих местах в 1101 году. По следам Буркхарда к подножью горы Гаруна последовали другие путешественники, начались поиски древних рукописей. Все прояснилось, когда у чудесного оазиса у горы Гаруна в начале XX века начались археологические раскопки. Оказалось, что этот город, поспешно названный именем Моисея, а позже «Красной скалой», на самом деле именовался римлянами Петрой (в переводе с греческого - «скала»).

Ученые считают, что места эти были обитаемы еще тысячелетия назад. Здесь, в долине у горы Гаруна, между Мертвым морем и Акабой проходили важнейшие торговые пути, соединяющие Средиземноморье и Египет с Аравией, Китаем и Индией. Одно время в этих местах 


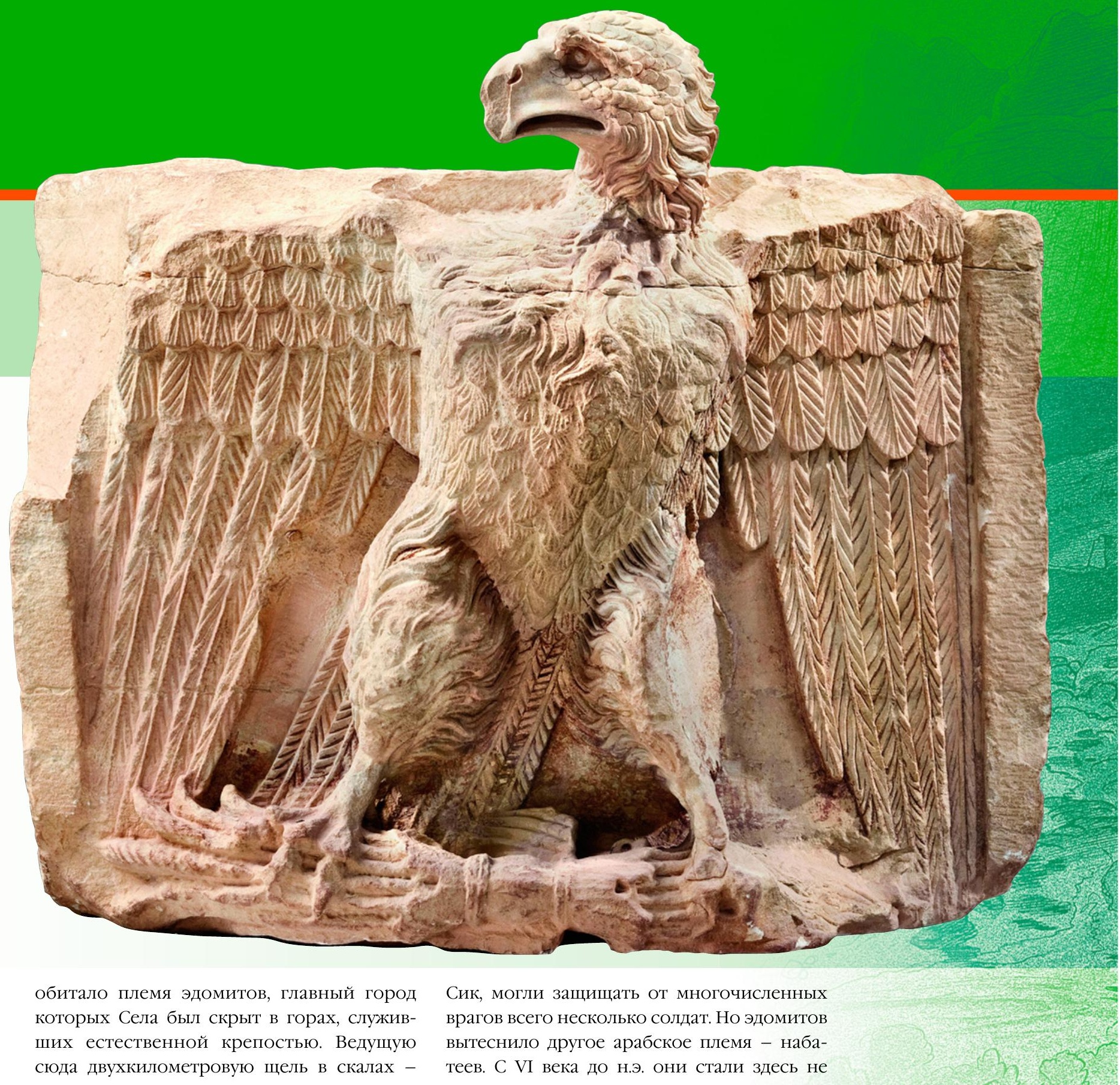

По следам Буркхарда к подножью горы Гаруна последовали другие путешественники, начались поиски древних рукописей. Все прояснилось, когда у чудесного оазиса у горы Гаруна в начале XX в. начались археологические раскопки. Оказалось, что этот город, поспешно названный именем Моисея, а позже «Красной скалой», на самом деле именовался римлянами Петрой (в переводе с греческого - «скала»). 


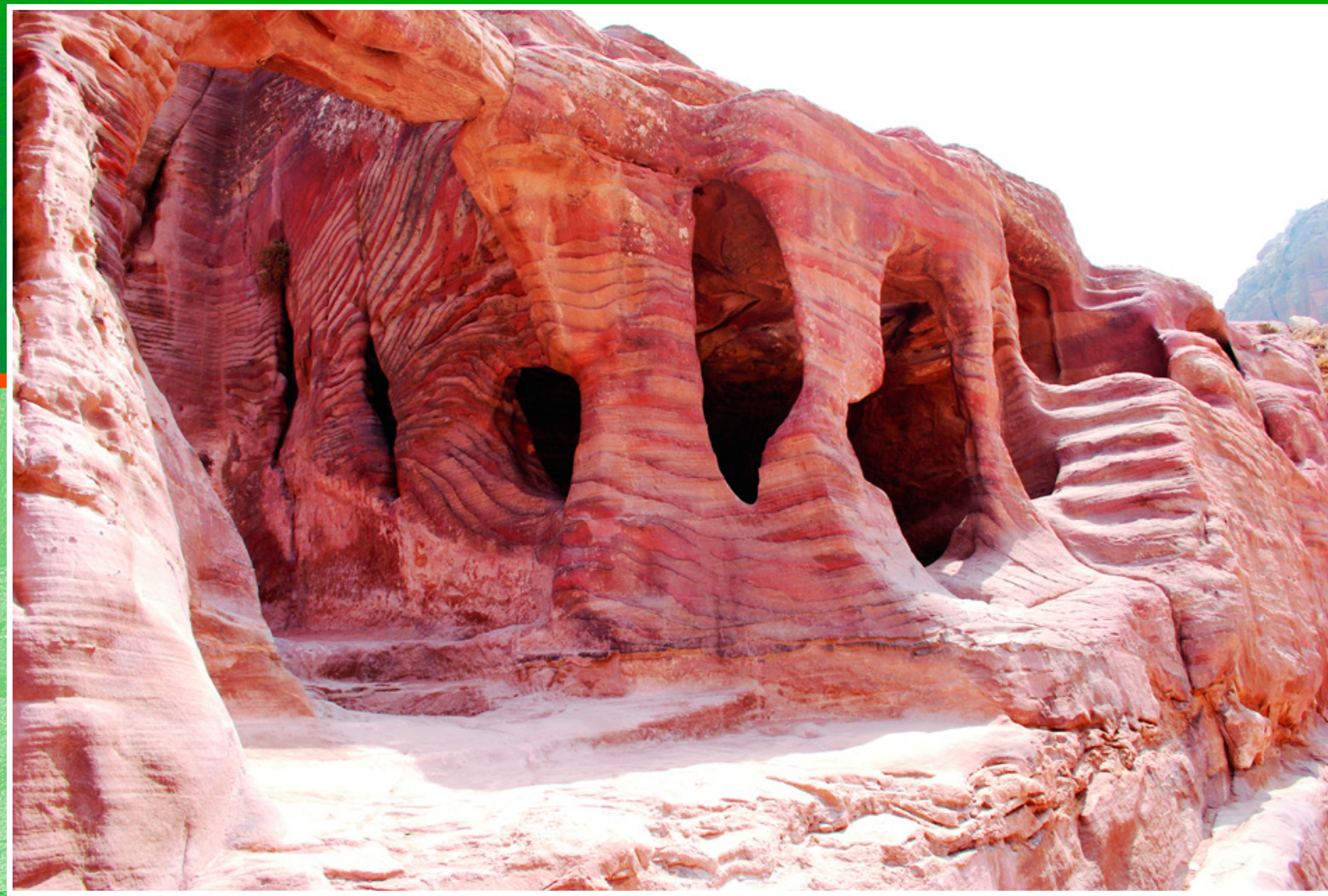

Иллюстрации на странице: Элементы архитектуры Петры.

Пещерные дома.

Капитель в виде слоновьих голов.

только полновластными хозяевами, но и покорили соседние племена всего района Синайских гор.

Набатеи держали под контролем важные караванные пути, их богатство и могущество отразилось и на столице у подножья Гаруна. Они собирали богатые урожаи, создавали величественные храмы, строили сложные оросительные системы. Имея в обиходе один из диалектов древнейшего арамейского языка, создали свою письменность, предшествовавшую арабской. Набатеи поклонялись камням, олицетворявшим богов, пантеон которых возглавлял набатейский Зевс - Душан. Почитание мертвых возводилось в культ - в гробницах и триклиниях проводились пышные поминальные трапезы и богослужения. Считалось, что как только погребенному переставали приносить еду, забывали о нем, он тотчас

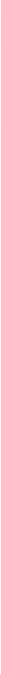




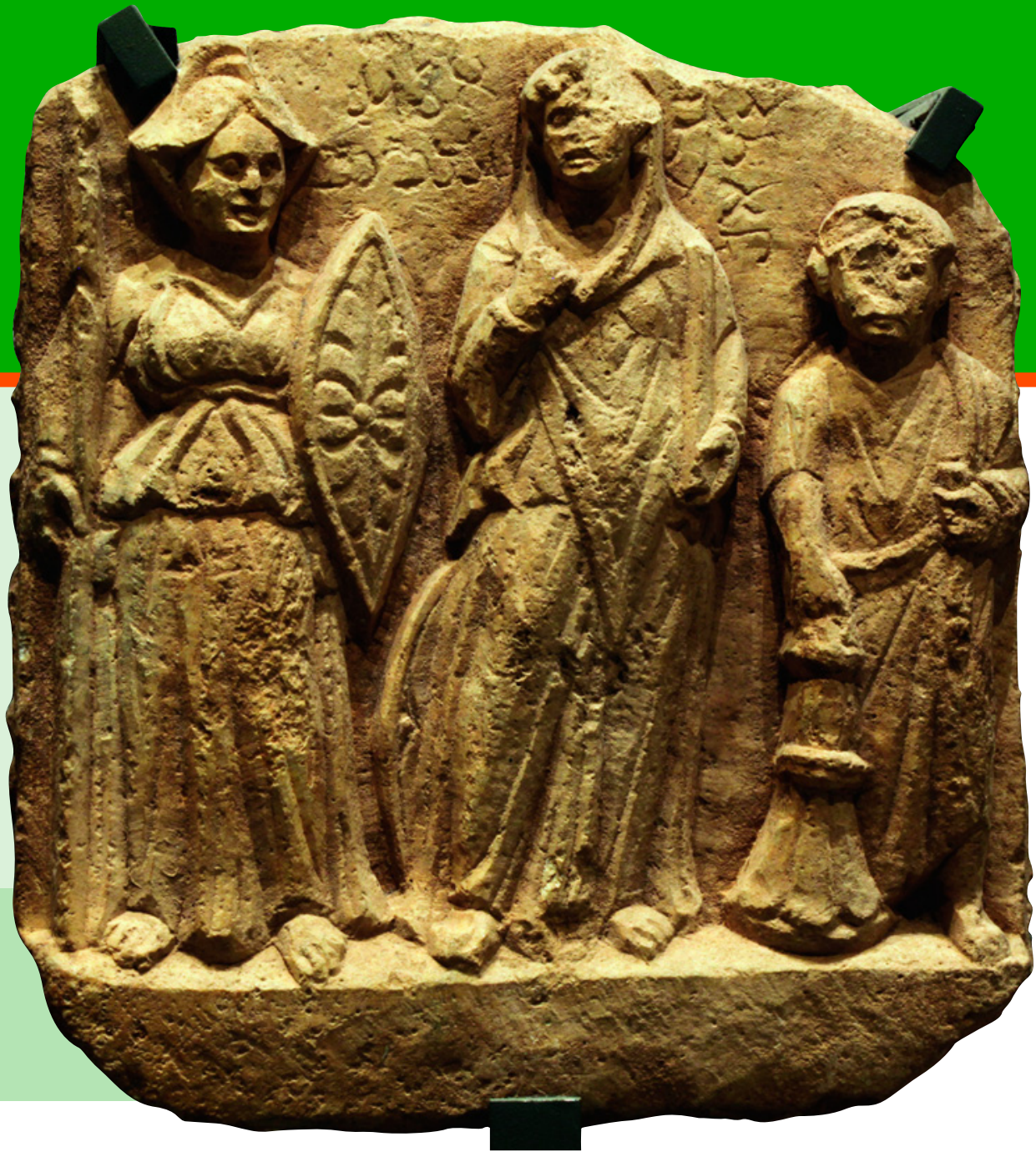

выходил из могилы и мстил за невнимание. При обилии захоронений и царского некрополя на 800 могил неудивительно, что еще совсем недавно Петру считали всего лишь городом мертвых. То и дело в скалах на разной высоте попадаются от- верстия, которые специалисты называют гробницами, хотя ни в них, ни во всем этом странном городе не удалось найти ни одного действительного захоронения. Факт особенно примечателен, ведь разрозненные свидетельства неопровержимо дока-
Богини набатеев Аль-Лат, Аль-Уззу и Манат были настолько почитаемы на Аравийском полуострове, что после принятия ислама их стали считать посредницами Аллаха, а посвящаемые богиням обряды стали частью исламского Хаджа. зали, что это было богатое поселение с населением не менее 20 тысяч человек. Благодаря особой системе водопроводов, город постоянно снабжался ключевой водой; жители пользовались бассейнами и банями, а по вечерам гуляли по центральной мощеной улице вдоль многочисленных торговых лавок.

В 106 году - в правление императора Траяна - Петра была покорена Римом. За время своего владычества римляне построили новые храмы, жилые и административные здания, хитроумные военные сооружения, модернизировали амфитеатр, расширив его до необходимых размеров, дополнили поселение нужными постройками. Из других неплохо сохранившихся архитектурных памятников римской эпохи выделяются Колоннада и Парламент.

Судя по найденным при раскопках Петры артефактам и архитектурным элементам, в разное время здесь жили также греки и египтяне. Позже побывали крестоносцы, они, как предполагают археологи, построили обе цитадели, расположенные в центре города.

Но дальше наступили времена упадка и запустения. Очередное землетрясение окончательно добило некогда сильное Набатейское царство, ставшее захудалой окраиной Древнего Рима. С падением империи потеряла свое значение и великолепная Петра. Еще какое-то время она была резиденцией византийского епископа, затем находили здесь убежище местные бедуины, но из-за частых землетрясений и они удалились подальше от скал. Мертвый город оказался забытым и погрузился в пучину забвения.

\footnotetext{
и они удалились подальше от скал.
} 